Discussion Paper No. 03-33

Reforming Social Welfare as We Know It? A Microsimulation Study for Germany

Viktor Steiner and Peter Jacobebbinghaus

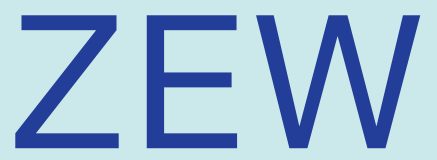

Zentrum für Europäische Wirtschaftsforschung GmbH

Centre for European

Economic Research 
Discussion Paper No. 03-33

\title{
Reforming Social Welfare as We Know It? A Microsimulation Study for Germany
}

\author{
Viktor Steiner and Peter Jacobebbinghaus
}

Download this ZEW Discussion Paper from our ftp server:

\begin{abstract}
ftp://ftp.zew.de/pub/zew-docs/dp/dp0333.pdf
\end{abstract}
Die Discussion Papers dienen einer möglichst schnellen Verbreitung von neueren Forschungsarbeiten des ZEW. Die Beiträge liegen in alleiniger Verantwortung der Autoren und stellen nicht notwendigerweise die Meinung des ZEW dar.

Discussion Papers are intended to make results of ZEW research promptly available to other economists in order to encourage discussion and suggestions for revisions. The authors are solely responsible for the contents which do not necessarily represent the opinion of the ZEW. 


\section{Non-Technical Summary}

The focus in the discussions of social welfare reforms in Germany is on the question how to increase work incentives in order to reduce unemployment and, at the same time, to stabilize or even reduce social expenditures. We argue that most proposals to increase financial incentives to take up work by some sort of wage subsidy programme or the other without reducing the social minimum are not an effective way to attain these aims. This unpleasant implication derives from the structure of the social welfare system and the rather compressed earnings structure. Thus, a successful reform which increases employment and, at the same time, avoids high marginal tax rates and constrains fiscal costs, requires a marked reduction in the social minimum. In this paper, we analyse the employment and fiscal effects of such a welfare reform with the following components: (i) an integration of unemployment assistance and social assistance; (ii) a substantial reduction of the social assistance level for "employable" persons who choose not to work; (iii) improved incentives to take up work by a combination of a reduction of the social assistance withdrawal rate and an earnings-related tax credit.

We estimate the employment effects of the proposed social welfare reform on the basis of a structural labour supply/demand model embedded in a detailed tax-benefit microsimulation model. On the basis of the structural labour supply model we also try to estimate the effect of the reduction of the social minimum for those "employable" people who choose not to work on the expected demand for public jobs and the budgetary costs of the welfare reform. Our simulation results show that the proposed welfare reform would increase employment by about 300 thousand persons. We also expect that about 300 thousand persons entitled to social assistance will take up a public-works job in order to avoid cuts in the social assistance level. In addition to a substantial employment increase, the introduction of the welfare reform proposal presented here would also lead to a yearly reduction in net social expenditures of almost 10 billion $€$. The lion's share of these savings comes from the integration of unemployment assistance into social assistance and the reduction of its level for those not willing to take up a regular or public-works job. Even taking into account the reduction in tax receipts induced by the decline in market wages, the net budgetary effect of the welfare reform will remain substantial. This may be even true if the financial costs for providing public-works jobs for those who are willing to take up jobs but do not find jobs in the private sector are taken into account, depending on how the public-works sector would be organized. 


\title{
Reforming Social Welfare as We Know It? A Microsimulation Study for Germany
}

\author{
Viktor Steiner *) \\ Peter Jacobebbinghaus **) \\ *) Freie Universität Berlin \\ DIW Berlin \\ IZA Bonn \\ **) ZEW Mannheim
}

\begin{abstract}
Social assistance and unemployment assistance, which provide means tested income support (social welfare) without pre-specified time limits, are viewed as one important reason for the persistently high level of unemployment in Germany by many economists. In order to increase work incentives and, at the same time, reduce social expenditures there have been various proposals to reform social welfare in the recent German policy debate. We analyse a specific reform proposal with the following components: (i) an integration of unemployment assistance and social assistance; (ii) a substantial reduction of the social assistance level for "employable" persons who choose not to work; (iii) improved incentives to take up work by a combination of a reduction of the social assistance withdrawal rate and an earnings-related tax credit. The expected employment and fiscal effects of this welfare reform proposal are simulated on the basis of an econometrically estimated partialequilibrium labour supply/demand model embedded in a detailed tax-benefit microsimulation model. We find that the reductions in net social expenditures may be substantial, although the expected labour supply and employment effects of this reform are much smaller than is typically assumed by contributors to recent discussions on the potential labour market effects of welfare reforms in Germany. Furthermore, these employment gains come at the cost of a substantial expansion of public-works jobs.
\end{abstract}

\section{Correspondence to:}

Prof. Dr. Viktor Steiner

DIW Berlin

Königin-Luise Str. 5

D-14195 Berlin

email: vsteiner@diw.de

Acknowledgement: We thank the Fritz Thyssen Foundation for financial support under the project "Verteilungseffekte und fiskalische Kosten von Lohnsubventionen im Niedriglohnbereich". 


\section{Introduction}

In the recent German debate on labour market and social reforms one of the most controversial issues relates to the alleged disincentive effects of social assistance and unemployment assistance. These programmes, which constitute the German version of "social welfare", provide means tested income support at a socially defined minimum income without a pre-specified time limit. There have been various recent proposals to reform social welfare with the intention to increase work incentives in Germany, some of them thereby also aiming to reduce social expenditures. To some extent, these proposals are motivated by the experience with welfare reforms in other countries, such as the Earned Income Tax Credit in the United States or the Working Families' Tax Credit in the United Kingdom (for a summary of these and similar programmes see, e.g., Blundell, 2002). On the one extreme are proposals relying exclusively on the "carrot" of wage subsidies of some sort or the other. Various ex ante evaluations for Germany have shown that these proposals are either completely ineffective in raising employment if targeted at the supply side or, if targeted at the demand side, involve extremely high budgetary costs (for a recent survey see, e.g., Buslei and Steiner, 2003). On the other extreme of this spectrum are recent proposals to "yield the stick" by cutting social welfare. Irrespective of the main focus of the various proposals, the general underlying approach seems to be to move away from "welfare" as practiced in Germany to a system more oriented towards "workfare" as in the US and some other European countries (Ochel, 2003).

The recent proposal by Sinn et al. (2002) includes a drastic reduction of the social minimum for "employable" people who choose not to work and, at the same time, improved financial incentives to take up work. Following this proposal, both the German Council of Economic Advisors (Sachverständigenrat, 2002) and the Scientific Council of the Federal Economics Ministry (Wissenschaftlicher Beirat, 2002) have put forward similar proposals, although without the drastic reduction of the social minimum for those who do not work (for recent surveys see Buslei und Steiner, 2003, Zimmermann, 2003). As we will argue below, by avoiding the unpopular cut in the social minimum, these latter proposals are not likely to achieve the aim of increasing work incentives and, at the same time, keep fiscal costs within sustainable limits. Although these proposed welfare reforms would improve work incentives for currently unemployed people, they imply either extremely high marginal tax rates in some part of the earnings distribution or a substantial increase in the number of people entitled to social welfare. Since these proposals do not provide empirical estimates of employment and budgetary effects, their relevance as basis for actual welfare reforms may by questioned. 
In this paper, we analyse the employment and fiscal effects of a welfare reform which combines a substantial reduction of the social minimum for people who choose not to work with improved financial incentives to take up work. Thus, the proposal analysed here is very similar to the one proposed by Sinn et al. (2002). However, our empirical approach to estimate these effects differs fundamentally from their hypothetical calculations. These authors simply assume that, as a result of the welfare reform, the market wage will fall to a level consistent with full employment of unskilled labour. This implies that all or at least the great majority of "employable" but currently unemployed persons would take up a job due to improved financial incentives to do so by way of a combination of a substantially reduced social minimum and a wage subsidy (Earned Income Tax Credit). In contrast, we estimate the potential labour supply effects of a similarly structured welfare reform on the basis of a structural labour supply model embedded in a detailed tax-benefit microsimulation model. On the basis of this model we derive the expected employment and budgetary effects of the welfare reform under the assumption of wage adjustment required to balance demand and supply in the labour market. On the basis of the structural labour supply model we also try to estimate the effect of the reduction of the social minimum for those "employable" people who choose not to work on the expected demand for public jobs and the budgetary costs of the welfare reform.

The evaluation of the analysed welfare reform is limited to the positive analysis of its employment and fiscal effects. We do not discuss the normative question whether the welfare reform proposal analysed here is efficient from a social welfare perspective. It can be argued that welfare reforms aiming at increasing employment by means of negative tax rates for people entitled to means tested income support or by introducing strict work requirements need not be socially efficient (see Saez, 2002, and Homburg, 2002, 2003). However, such a normative analysis would be conditional on the specification of some social welfare function for which there is little empirical basis and, in any case, no political consensus.

In the next section, we briefly describe the current problems of the German welfare system, discuss recent proposals to reform it, and present a detailed welfare reform proposal similar to the one recently suggested by Sinn et al. (2002). In section 3, we present the empirical methodology to simulate the employment and fiscal effects of this proposal. The discussion focuses on the econometric specification of our household labour supply model, the derivation of the employment effects within a partial-equilibrium labour market model, and the calculation of fiscal effects. Simulation results of the employment and fiscal effects of our welfare reform proposal are contained in section 4. Section 5 summarizes the main results of our study and contains some conclusions. 


\section{How to Reform Social Welfare?}

The German social welfare system, as we define it here, consists of social assistance (SA) and unemployment assistance (UA) which both provide means tested income support without prespecified time limits (a brief summary of the current structure of this two-tier system is provided in Appendix 1). ${ }^{1}$ Among economists and the general public alike, the view has increasingly become popular that this system has contributed to the high level of unemployment in Germany. ${ }^{2}$ There are basically two arguments for this belief: The first is that, due to the small difference between net income from full-time employment in a low wage job and the level of SA for certain household types, there is no or very little financial incentive to take up work in the regular economy. In other words, the benefit withdrawal rate for social welfare recipients is simply too high, and this negative incentive effect is reinforced by high social security contributions and income taxes which already set in at relatively low earnings. The other argument refers to the role of social welfare in sustaining a relatively high market wage: the social minimum effectively sets a lower wage floor for low-skilled labour. Although the basic problem according to both views is really the relatively high level of social welfare, the first view stresses the supply side, whereas the second emphasizes the demand side of the market for low-skilled labour. Of course, both sides of the labour market are affected, and these arguments are complementary rather than substitutes for each other.

Various approaches are suggested in the literature and in the economic policy debate to make work financially more attractive relative to non-work. One approach relies on the "carrot" of wage subsidies. This may be administered by reducing the benefit withdrawal rate of social welfare, subsidies to social security contributions, a negative income tax on low earnings, or a combination of these instruments. These wage-subsidy programmes have been relatively popular in the economic policy debate, but are unlikely to have large employment effects if fiscal costs are to be contained, as various simulation studies have shown (see, e.g., Buslei and Steiner, 2003, for recent summaries of research for Germany). Another approach combines the carrot of wage subsidies with the "stick" of a reduction of social welfare for those who choose not to work.

1 Most unemployed people are entitled to unemployment benefits which are not means tested but depend on an individual's previous employment periods covered by the social security system, and are available for a prespecified time period (typically 12 months, except for older workers). Since unemployment benefits are not directly affected by the social welfare reform we do not discuss their structure here.

Recent prominent subscribers to this view include Sinn et al. (2002), the German Council of Economic Advisors (Sachverständigenrat, 2002), and the Scientific Council of the (former) Federal Economics Ministry (Wissenschaftlicher Beirat, 2002). 
As argued in Steiner (2000, 2002), the dilemma of the German welfare system is the impossibility to retain the high level of the social minimum (for larger households) relative to the average level of earnings, increase incentives to take up low wage work by reducing the benefit withdrawal rate for social welfare and, at same time, constrain fiscal costs within sustainable limits. The reason for this fact is that, given a relatively high social minimum and a fairly compressed earnings structure, a social welfare withdrawal rate substantially below $100 \%$, as it would be required for improving work incentives, implies either significantly higher marginal tax (withdrawal) rates over some part of the earnings distribution or the extension of social welfare eligibility to households with relatively high earnings, or a combination of both.

In the remainder of this section we take this consideration into account and specify a welfare reform proposal with the following three basic components:

(i) The integration of social and unemployment assistance into one social welfare payment with entitlement conditional on the means test currently applied to SA.

(ii) The SA level for "employable" persons who choose not to work is reduced substantially. All people receiving SA are offered a full-time public works job at the current SA rate.

(iii) Incentives to take up work shall be improved by a combination of a reduction of the social assistance withdrawal rate and an earnings-related tax credit.

The first component of this welfare reform proposal is probably the least controversial one, at least among economists. Since SA and UA are both means tested social welfare payments, there is really no reason to differentiate between the two on distribution grounds. Furthermore, a major aim of welfare reforms is to reduce long-term unemployment which has been shown to be strongly affected by the availability of UA for an unlimited entitlement period (see Steiner, 1997, 2002).

A significant reduction of the SA level for "employable" persons who choose not to work would also be not very controversial, in principle, since it is already mandatory under existing law. The problem rather is to define what "employable" means, and how a conclusive work-test can be implemented. In fact, there is no operational generally accepted definition of “employability”. In this study, we define people as employable if they are aged between 18 and 65 years, are not severely disabled, are not in full-time education or on maternity leave. From this group we exclude one person per household if children below the age of 14 years or severely disabled persons are taken care of. If there are still one or more employable persons living in the household, it is marked "employable". In these households the SA rate is cut by 
$50 \%$. This implies that, on average, the social minimum also including housing costs paid for directly by the social welfare administration is reduced to about $70 \%$ of its previous level.

In order to improve work incentives, the SA withdrawal rate is cut to zero until earnings reach the status quo SA level. In other words, recipients of SA who take up work may keep every $€$ they earn until the status quo SA level is reached. If individual earnings exceed that level the SA withdrawal rate reaches $70 \%$. Furthermore, a tax credit is introduced to avoid the disincentive effect of social security payments. It amounts to $20 \%$ of individual gross earnings exceeding $325 € .^{3}$ For singles the tax credit covers a degressive share of the employee's social security payments up to monthly earnings of $820 €$. For couples the tax credit covers social security payments if earnings are below $650 €$ and a degressive share is covered up to monthly earnings of $1620 €$. In the calculation of SA the tax credit is accounted for as earned income. Therefore, for SA recipients facing the SA withdrawal rate of $70 \%$ most of the tax credit is compensated for by the reduction of SA. The resulting implicit marginal tax rates for various household types are discussed below.

As to the work-test, the only really conclusive one is based on a job offer by the social welfare administration or local labour office. Lack of job offers at the administration's disposal is generally considered to be the main reason for the small number of temporary reductions or terminations of social welfare payments to recipients suspected not to be willing to take up work because the administration fears to have to prove the case in court. Given the high unemployment rate, the actual availability of public-works jobs may also be a political prerequisite for a reduction of the social minimum. As discussed below, this reduction has to be substantial if financial incentives shall be improved significantly and, at the same time, budgetary costs of the reform are to be constrained within sustainable limits.

The marginal tax rate, as we define it here, includes not only the SA benefit withdrawal rate, housing allowance, the income tax which sets in at an income level of about $800 €$ for a single person, but also an implicit wage subsidy which is withdrawn with increasing earnings. This latter component of the welfare reform proposal may be called an Earned Income Tax Credit (EITC) which, considered in isolation from the other components of the tax-benefit system, implies a negative marginal tax rate for very low earnings. ${ }^{4}$ In the German case, a tax credit would interact with various other components of the tax-benefit system, and this is best accounted for by the marginal tax rate. Figure 1 illustrates the implications of the reform

\footnotetext{
3 In April 2003 the lower earnings threshold for social security payments will be raised to $400 €$ followed by a progressive rate reaching the full rate at monthly earnings of $800 €$.

4 For descriptions of the EITC implemented on a large scale in the US see Ochel (2003).
} 
proposal with respect to net household incomes and marginal tax rates and compares them with the current system for various household types.

To start with the graphs for singles without children in the upper part of Figure 1, we note that, due to the substantial reduction of the social minimum, net household income after the reform would always lie below the income level under the status quo until gross earnings reach $870 €$, where the two lines coincide. The upper-right panel of Figure 1 shows that up to that level of gross earnings the marginal tax rate under the reform always lies below the one for the status quo, and this difference is about 20 percentage points in the range between 680 and $870 €$.

As shown in the middle part of Figure 1, single parents with one child could increase their net household income after the reform by expanding their labour supply: between 785 and $1620 €$ gross earnings post-reform net household income would be substantially higher than under the status quo. Marginal tax rates after the reform would be substantially below current levels over a substantial rate, and the maximum marginal tax rate would never reach $100 \%$, in contrast to the current system. However, between 1100 and $1620 €$ marginal tax rates under the reform would be somewhat higher than under the status quo. This is a direct implication of the now markedly lower marginal tax rates in the lower part of the earnings distribution.

In the lower part of Figure 1, the implications of the reform proposal for a couple with two children are illustrated. The emerging picture is similar as described in the previous paragraph. Net household income increases with rising gross earnings of the household over the range of 1010 and $1630 €$. Over a wide range, marginal tax rates under the reform are substantially below those prevailing under the status quo. Post-reform marginal tax rates reach the maximum at $80 \%$ compared to $100 \%$ under the status quo.

Overall, the described welfare reform would improve incentives to take up work, especially for larger households and single parents. By reducing the social minimum substantially for persons who choose not to work, the marginal tax rate on low earnings can be significantly reduced without shifting the cut-off point for social welfare too far to the right of the earnings distribution. However, the significant reduction of the marginal tax rate at the lower end of the earnings distribution implies that for larger households and single parents the marginal tax rate under the reform is higher than under the status quo over some range in the middle of the earnings distribution. 
Figure 1-Gross earnings, net household income and marginal tax rates under the current system and under the reform proposal

\section{Singles without children}
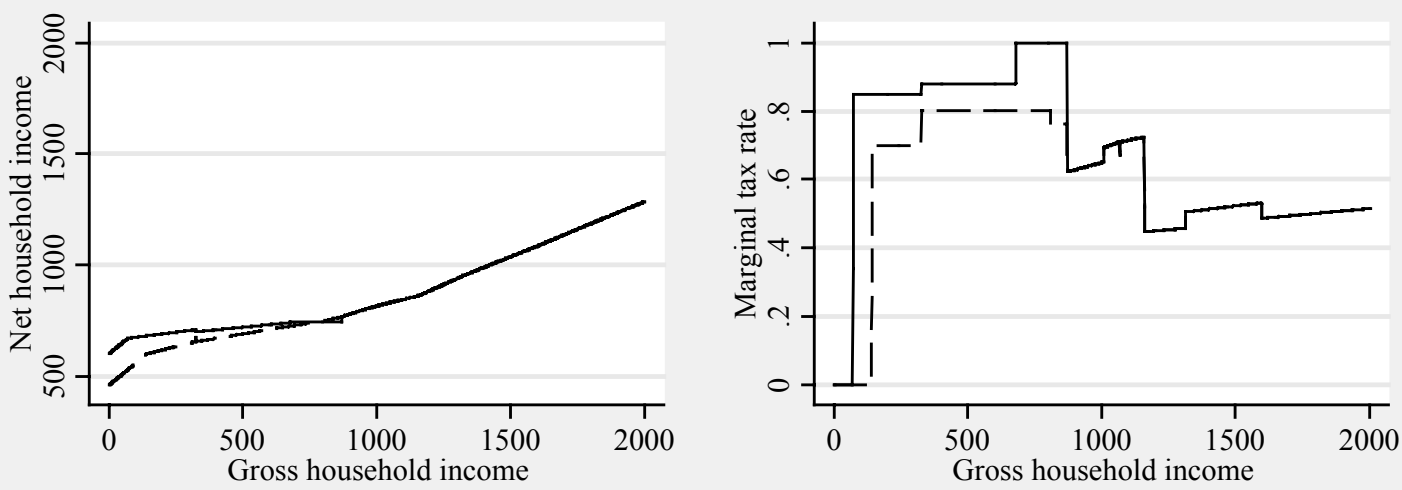

Singles with one child
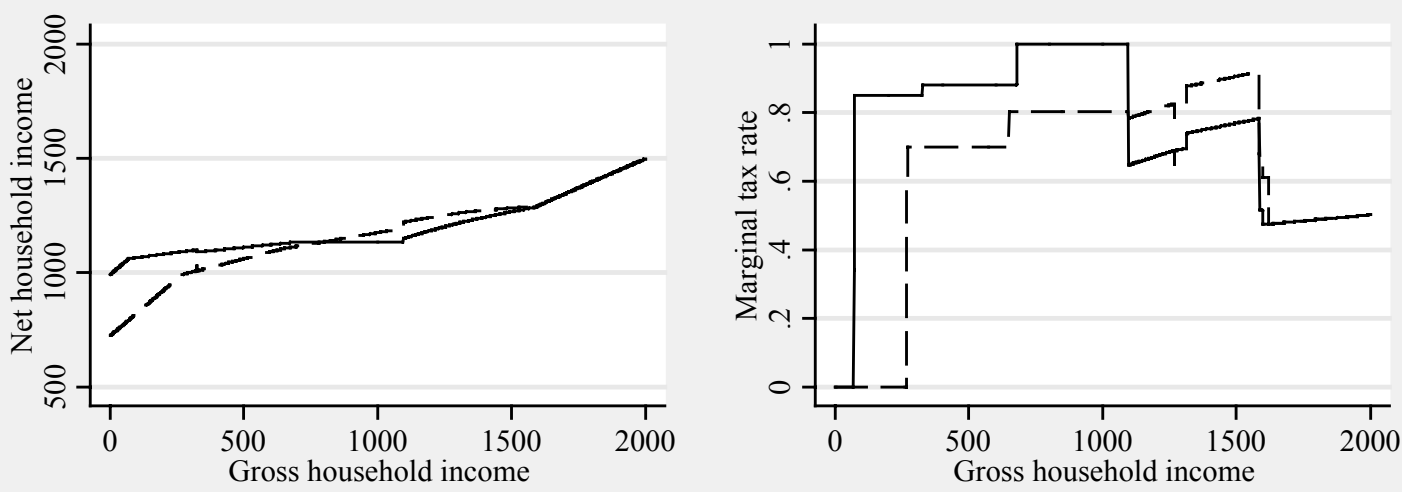

\section{Couples with two children}
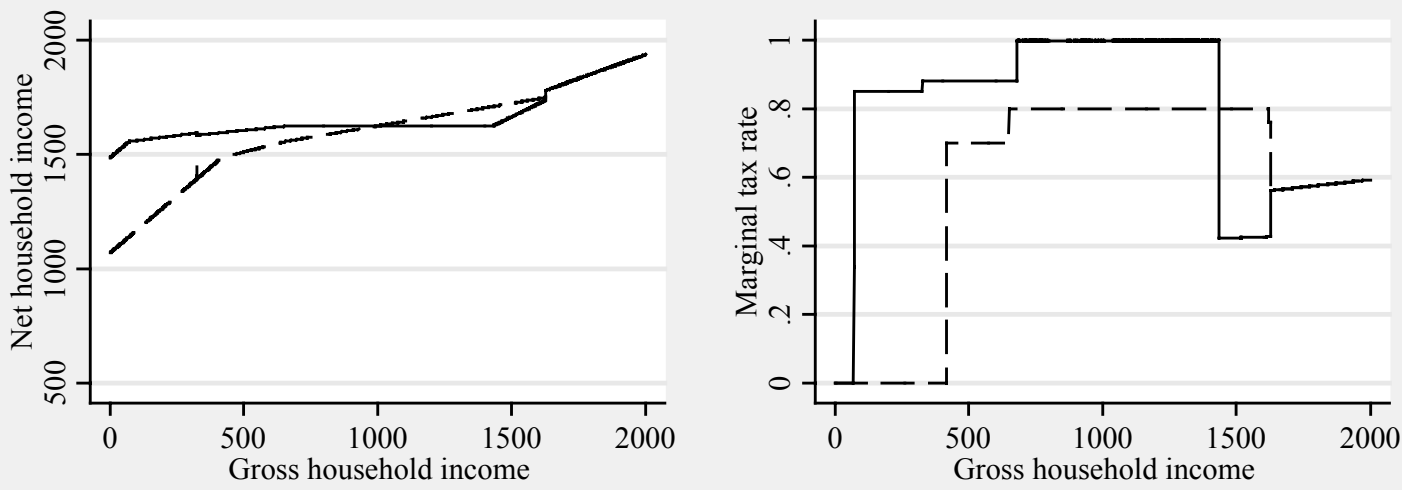

\section{Status quo}

- - - Reform proposal

Notes: Simulations refer to households with earnings as the sole source of income and take into account average deductions (Werbungskosten- and Sonderausgabenpauschale), child(ren) allowances, and the tax tariff for 2002 (including 5.5\% solidarity surcharge). For singles the basic household allowance and for couples „income splitting“ are applied in calculating the tax rate. The assumed social assistance rate of $282 €$ per month is an unweighted average for all German states. Average values were also assumed for tabulated housing subsidies and heating costs. 


\section{Simulation Methodology}

In this section, we describe our methodology to simulate the employment and fiscal effects of the proposed welfare reform outlined in the previous section. We start with a brief methodological discussion of the various labour market effects of a reduction of social welfare. This discussion aids our simulation analysis which is based on an empirical household labour supply model embedded in a detailed tax-benefit simulation model. In section 3.2 we present the econometric specification of our labour supply model. Employment termination under wage adjustment is discussed in section 3.3, and the various fiscal effects induced by the welfare reform are briefly discussed in section 3.4 .

\subsection{How does the Reform Affect Labour Supply, Wages, and Employment?}

The basic assumption underlying the proposed welfare reform is that the reduction of nonwork income and the simultaneous reduction of the marginal tax rate on earnings will increase the supply of labour at any given gross wage and, thus, employment if there is sufficient downward wage adjustment. This is illustrated by way of the standard partial-equilibrium labour market model in the following figure.

Figure 2-Labour supply, wage and employment effects of a reduction in social welfare in a partial-equilibrium labour market model

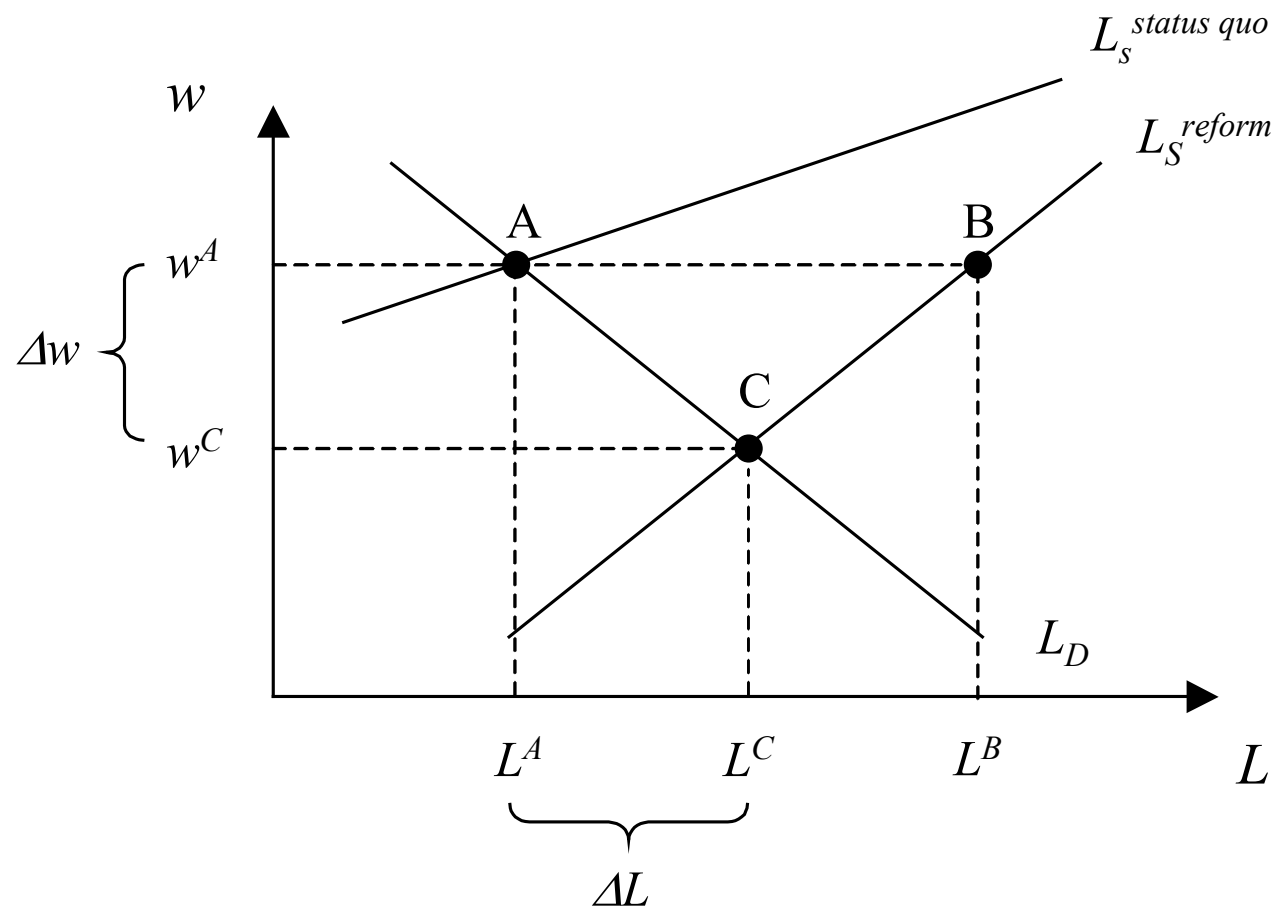


In Figure 2, the positively sloped labour supply curve is drawn under the assumption that an individual's reservation wage depends on the availability of social welfare, and that this effect is particularly strong for those with relatively low potential earnings. A reduction in means tested income support for the unemployed would therefore shift the labour supply, as illustrated in Figure 2. If the labour demand curve was perfectly elastic, market wages would stay constant at $\mathrm{w}^{\mathrm{A}}$ and the employment effect would be given by the increase in labour supply, i.e. the distance $\overline{A B}{ }^{5}$ However, allowing for a negatively sloped demand curve for labour, the increase in labour supply will only be absorbed by increased demand if the market wage falls. As illustrated in Figure 2, in the new equilibrium given by point $C$, the gross wage has fallen to $w^{\mathrm{C}}$ and employment has increased less than in $B$ due to the adjustment of labour supply to the wage reduction. For a given shift in the labour supply, the required wage reduction will be determined by the size of the wage elasticity of labour demand: the larger (in absolute value) the labour demand elasticity, the greater the employment effect.

To simulate the employment effects of the proposed welfare reform, we thus need to estimate the induced labour supply shift and the required wage change which balances supply and demand in the labour market. ${ }^{6}$ These responses depend on the effect the welfare reform has on household incomes and the relevant elasticities of labour supply, both with respect to labour force participation and total hours. A detailed description of the econometric specification of the household labour supply model from which these elasticities can be derived is provided in the next section. This model is embedded in a detailed tax-benefit model which includes all relevant components of the German tax and transfer system and uses data from the German Socio Economic Panel (GSOEP) for the period 1997 to $2000 .{ }^{7}$ A brief description of the tax-benefit simulation model is contained in Appendix 2.

\subsection{Econometric Specification of the Household Labour Supply Model}

We specify a household utility model based on the assumption that both spouses jointly maximize a utility function in the arguments leisure of both spouses and net household

5 Given that there is a large number of vacancies in the German low wage labour market even in times of high unemployment rate, it is conceivable that a modest increase in the supply of labour could be absorbed at a given market wage.

6 Thus, our approach differs fundamentally from the one in Sinn et al. (2002) who simply ask by how much the gross wage would have to drop in order to induce the demand for unskilled labour to increase so that a given number of ("employable") persons could be employed assuming that labour supply is perfectly elastic at the going wage rate. Their approach only requires an estimate of (or assumption about) the wage elasticity of the demand for unskilled labour.

7 A description can be downloaded from www.diw.de/soep; see also Haisken-DeNew and Frick (2001). 
income. ${ }^{8}$ To make the household labour supply model tractable, we assume that the labour supply decisions of the household head and the spouse can be separated from the labour supply decisions of all other household members. That is, it will be assumed that other household members' labour supply does not affect the spouses' joint labour supply decision. For singles, the specification of the labour supply model is just a special case of the household utility model with all interaction terms between the spouses' leisure variables set equal to zero in the utility function (see equation (1) below). The analysis is restricted to household members aged between 20 and 60 years who can be expected to vary their labour supply to changes in potential net income. Hence, pensioners, students in full-time education and women on maternity leave are not included in the sample. The self-employed and civil servants are also excluded because their labour supply behavior can be expected to differ qualitatively.

Given the complexities of the German tax and income transfer systems and the existence of means tested social transfers, a detailed specification of the household's budget constraint is crucial when analyzing the incentive effects of the proposed welfare reform. Here, we approximate the household's budget constraint by a relatively small number of discrete points which represent discrete labour supply choices of couples and singles respectively (see Table A1 in Appendix 3). From an empirical perspective, this also accounts for the fact that working hours are heavily concentrated at particular hours, such as $0,15,20$ and 40 hours for women, and 0 and 40 hours for men.

The household's labour supply decision is modelled by a utility function which is assumed to depend on the leisure time of the male $\left(L_{\mathrm{m}}\right)$ and the female $\left(L_{\mathrm{f}}\right)$ spouse as well as on real net household income (Y). Following van Soest (1995), we assume that the household's utility index for a particular hours category, $k$, can be approximated by the following translog function:

$$
U_{k}\left(x_{k}\right)=x_{k}^{\prime} A x_{k}+\beta^{\prime} x_{k}+\varepsilon_{k}
$$

where $x=\left(y, l_{\mathrm{m}}, l_{\mathrm{f}}\right)$. The components of $x$ are the (natural) logs of net household income, leisure of the husband and the wife, respectively. These components enter the utility function (1) with linear, quadratic and cross terms between the spouses' leisure terms and household income. The matrix $A$, with elements $\alpha_{\mathrm{ij}}, i, j=(1,2,3)$, contains the coefficients referring to the non-linear terms, the vector $\beta_{\mathrm{j}}, j=(1,2,3)$, the corresponding coefficients of the linear

8 For a recent summary of household labour supply models see Blundell und MaCurdy (1999). 
terms. The variable $\varepsilon$ is a stochastic error term accounting for factors affecting the household's utility other than leisure and income, its distribution is specified below.

The utility index should be concave in household income and, for given household income, be increasing in both spouses' leisure time (provided working hours were initially positive). Moreover, the first derivative of the utility index with respect to leisure time should, ceteris paribus, be positive for both spouses, provided leisure is a normal good, while the second derivative should be negative. In the $H U$ model, the cross-substitution effect between the two spouses' leisure time is theoretically ambiguous. That is,

$$
\frac{\delta U(\cdot)}{\delta y}>0 ; \quad \frac{\delta^{2} U(\cdot)}{\delta y^{2}}<0
$$

$$
\begin{aligned}
& \frac{\delta U(\cdot)}{\delta l_{f}}>0 ; \quad \frac{\delta U(\cdot)}{\delta l_{m}}>0 ; \\
& \frac{\delta^{2} U(\cdot)}{\delta l_{f}{ }^{2}}<0 ; \quad \frac{\delta^{2} U(\cdot)}{\delta l_{m}{ }^{2}}<0 ; \quad \frac{\delta^{2} U(\cdot)}{\delta l_{f} \delta_{m}}=? ; \quad \frac{\delta^{2} U(\cdot)}{\delta l_{m} \delta_{f}}=?
\end{aligned}
$$

These theoretical implications can be tested by calculating respective derivatives of the utility index for each household evaluated at the parameter estimates from the econometric model described below. The sign of the cross effects depend on whether the two spouses' leisure time are substitutes or complements and can only be determined empirically.

Given the assumption of joint maximization of household utility, the household will choose hours category $k$ if, in probability terms, the associated utility index $U_{\mathrm{k}}$ exceeds the utility in any other possible alternative $l$, i.e.:

$$
P\left(U_{k}>U_{l}\right)=P\left(\left(x_{k}^{\prime} A x_{k}+\beta^{\prime} x_{k}\right)-\left(x_{l}^{\prime} A x_{l}+\beta^{\prime} x_{l}\right)>\varepsilon_{k}-\varepsilon_{l}\right), \quad \forall l \neq k
$$

To obtain an estimable econometric specification of the household labour supply model described in the previous section, we have to specify a distribution of the stochastic component of the utility function, i.e. $\varepsilon_{k}$. Assuming that $\varepsilon_{k}$ is distributed identically across all hours categories according to an extreme-value distribution, the difference of the utility index between any two hours categories follows a logistic distribution. As it is well-known (McFadden, 1974) under this distributional assumption the probability of choosing alternative $k$ relative to alternative $l$ can be described by the Conditional Logit Model, i.e.: 
(4) $P\left(U_{k}>U_{l}\right)=\frac{\exp \left(x_{k}^{\prime} A x_{k}+\beta^{\prime} x_{k}\right)}{\sum_{m} \exp \left(x_{m}^{\prime} A x_{m}+\beta^{\prime} x_{m}\right)}, \forall l \neq k$

where the summation sign is defined over all possible alternatives, i.e. hours categories.

For given levels of income and leisure for both spouses, household utility also depends on certain household characteristics, such as the age and the health status of both spouses as well as the number and age of children in the household. This dependence is accounted for in the model by specifying the parameters $\beta_{\mathrm{j}}$ as functions of these variables. Characteristics specific to the household or the spouses, like the presence of children, disability or age are identified by the assumption that their effects on household utility depend on the hours category. Potential differences in household preferences for leisure and income between East and West Germany, between natives and foreigners, and with respect to other individual and household characteristics, such as age, disability and the presence of children, are accounted for by interaction terms with (the logs of) net household income and the leisure variables. The derivation of potential net household incomes for each hours category is described in Appendix 2.

Estimation of the labour supply model is done by the Maximum Likelihood Method and based on the GSOEP for the year 1999. The quantitative implications of the model can best be summarized by hours and participation elasticities with respect to the gross wage rate which are summarized for various groups in the upper part of Table A2 in Appendix 3. ${ }^{9}$ Overall, estimated own wage elasticities are rather small and range between 0.40 for West German wives and $0.10-0.20$ for husbands with respect to hours worked. Similar differences are also observed with respect to participation elasticities. In contrast, cross-wage elasticities between wives and husbands are negligible in both regions and for all household groups considered here. This holds for both hours worked and labour force participation rates. With respect to total hours, the largest elasiticity is estimated at 0.15 for German married women. As expected, hours elasticities are relatively small for men in general. We also find that labour supply elasticities for foreigners are considerably smaller than for natives, both for men and women.

\subsection{Wage Adjustment and Employment Effects}

As described in section 3.1, to calculate the employment effects resulting from the shift of the labour supply curve induced by the policy reform we require an estimate of the wage

9 Detailed estimation results are available from the authors upon request. 
elasticitiy of labour demand, $\eta$. The percentage change of the gross wage required to balance the increase in the supply of labour $(\Delta L / L)$ induced by the welfare reform with the demand for labour is given by:

$$
\frac{\Delta w}{w}=\frac{\Delta L}{L} \frac{1}{\eta}
$$

Thus, for $\eta=-1$ a given proportional increase of labour supply requires the same relative reduction of the gross wage in the new equilibrium, for $\eta=-0.5$ it would have to be twice as large. Since the increase in supply differs across the various groups, for given $\eta$ the wage reduction would differ across groups.

Instead of simply assuming a specific value for $\eta$, we use the elasticity estimates derived in our previous work on the basis of an econometric model of the demand for heterogeneous labour. To determine the employment effect we require an estimate of $\eta$ with respect to the demand for persons. Since the degree of wage adjustment required to balance demand and supply in the labour market depends on the change in total hours supplied, we also require estimates for $\eta$ with respect to the demand for total hours. Elasticities at the extensive and intensive margins of labour demand may differ if persons and hours are not perfect substitutes in production. For institutional reasons, these elasticities may also differ by gender.

The elasticity estimates we use in this study are summarized in the lower part of Table A2 in Appendix 3. They refer to unskilled workers in the whole economy and are differentiated by gender. Compared with other studies for Germany, which typically refer to persons only, these estimates are in the intermediate range (for a survey see, e.g., Franz 2003, chapter 4). In absolute value, the largest own-wage elasticity refers to unskilled men. The estimated elasticity implies that an increase in this group's real wage by $10 \%$ reduces the demand for unskilled male workers by $6.5 \%$. The estimated elasticity with respect to total hours is virtually identical for this group. This implies that a change in the demand for unskilled labour leads to proportional employment adjustments within one year rather than to changes in average hours worked. This contrasts sharply with the demand for unskilled female labour which is adjusted mainly by changes in total hours rather than the number of employed unskilled women: Whereas the demand for total hours of unskilled women is reduced by $4.5 \%$ within a year following an increase of this group's real wage by $10 \%$, the corresponding reduction in the demand for unskilled women is only $1.7 \%$. These differences 
in employment adjustment can be explained by the much higher share of females doing parttime work which apparently makes it relatively easy to adjust working hours of women.

Using these labour demand elasticities and the estimated labour supply elasticities reported for the various groups in the upper part of Table A1, we simulate the employment effects of the policy reform. We first calculate the induced labour supply response for given market wages and then derive the wage reduction required to balance the implied increase in supply with the demand for total hours by iterating labour supply and wage adjustments until the new equilibrium values for employment and wages are obtained.

To test the sensitivity of simulated employment effects with respect to the estimated labour demand elasticities, we also report employment effects derived from the partialequilibrium labour market model under an assumed elasticity of -1 without differentiating between the demand for persons and for total hours. ${ }^{10}$

\subsection{Budgetary Effects}

In addition to the expected employment effects of the proposed social welfare reform, its budgetary effects dominate public policy discussions. Given the current budgetary situation in Germany, any reform proposal will be judged with respect to its implications for fiscal balances. Here, we will therefore provide some rough calculations of the expected budgetary consequences of the suggested SA reform proposal where we focus on the following fiscal effects:

(i) On the one hand, the termination of UA implies a huge reduction in public expenditures currently financed by federal taxes. These expenditures include both cash transfers to persons currently entitled to UA and contributions to the public pension, health and long-term care systems for these people.

(ii) On the other hand, depending on the relative strictness of the means tests for UA and SA a certain share of former UA recipients will become entitled to SA. This will increase SA expenditures currently borne by communities. At the same time, expenditures will be reduced due to the substantial reduction of the social minimum for "employable" SA recipients who choose not to take up work.

(iii) To the extent that the reform increases employment, income taxes and social security contributions will increase. To some extent this will be balanced, however, by the reduction of the marginal tax rate for low earnings implied by the reform proposal.

10 This is the assumption on which the calculations in the study by Sinn et al. (2002) are based. 
Furthermore, to the extent that there is downward (nominal) wage adjustment the wage tax will be reduced.

(iv) Some expenditures and (lost) receipts for the various layers of the fiscal system induced by the reform tend to cancel each other out as far as the consolidated fiscal budget (including social security) is concerned.

(v) The financing of public works for "employable" persons who do not find work in the private sector entails additional public expenditures. To the extent that public works are productive, these expenditures exceed their fiscal costs.

Since expenditures and receipts under (iv) just distribute funds among the federal government, communities, and the social security system, we will abstract from them here. For various reasons, we also do not take into account fiscal costs (v). It is almost impossible to estimate the additional number of public works jobs induced by the reform. Furthermore, even if this number could be estimated with some accuracy, it is not clear what financial value, if any, should be attached to public works.

However, our simulations will account for the fiscal effects (i) to (iii) in our calculation of the budgetary costs of the proposed welfare reform in section 4.2. At the level of individual households, the reduction of UA expenditures is partially balanced by a larger number of household becoming eligible to social assistance and by increased other means tested social transfers, such as housing subsidies. Furthermore, the lower SA withdrawal rate increases the income level at which SA is completely withdrawn for all household types. This implies a larger number of households who become eligible to SA. Furthermore, currently employed people may become eligible for or receive a larger amount of SA after the reform by reducing their working hours.

Whether or not persons who were entitled to UA before the reform become entitled to SA depends on other household income and wealth with a now stricter means test. The reduction of SA only concerns households with at least one "employable" member who chooses not to work. To calculate the level of SA expenditures after the reform would require an estimate of the number of currently entitled persons who would actually choose not to work after the reform and would therefore have the SA level cut.

We estimate this number on the basis of our structural labour supply model under the simplifying assumption that the disutility of work in a public-works programme is the same as in a private low wage job. From the estimated household labour supply model, we can calculate for each household affected by the reform two utility levels: First, the household's utility given the current level of the social minimum and the reduced leisure time associated 
with the specific work requirement imposed under the welfare reform. Second, the household's utilility given no work (full leisure) and reduced level of the social minimum applicable under the welfare reform. Comparing the two utility levels for each household affected by the reform, we can estimate the number of households whose social minimum will be cut and the resulting reduction in SA expenditures.

Since the disutility of work in a public-works job may be lower than in a low wage job in the private sector, we will probably underestimate the number of persons who choose not to take up a public-works job and thus overestimate the actual reduction in SA expenditures. Furthermore, there may also be persons currently employed in regular low wage jobs who, depending on the household's current level of the social minimum, may choose to take up a public-works job because of the possibly lower disutility of work in such a job. We will not take this possibility into account in our calculations, since there is no way to estimate the size of this potential effect on the basis of our labour supply model.

\section{Simulation Results}

The following presentation of our simulation results proceeds in three steps. In the next section we describe the non-behavioral effects of the analysed welfare reform by looking at the distribution of people and households directly affected by it. In section 4.2 we present and discuss the simulated labour supply and employment effects of the reform, and in section 4.3 we report on its expected budgetary effects.

\subsection{Who Would be Affected by the Welfare Reform?}

Table 1 summarizes the non-behavioral effects of the analysed welfare reform, i.e. the simulations abstract from any labour supply and wage effects induced by the reform. In addition to the number of households affected by the welfare reform and the distribution by type of households we also report the number of persons with a reduction in UA and SA, respectively, and also the share of winners and losers of the reform as well as the average reduction in social transfers. Since labour market conditions and incomes still differ substantially between East and West Germany simulation results are also reported separately for the two regions. 
Table 1-Non-behavioral effects of the analysed welfare reform

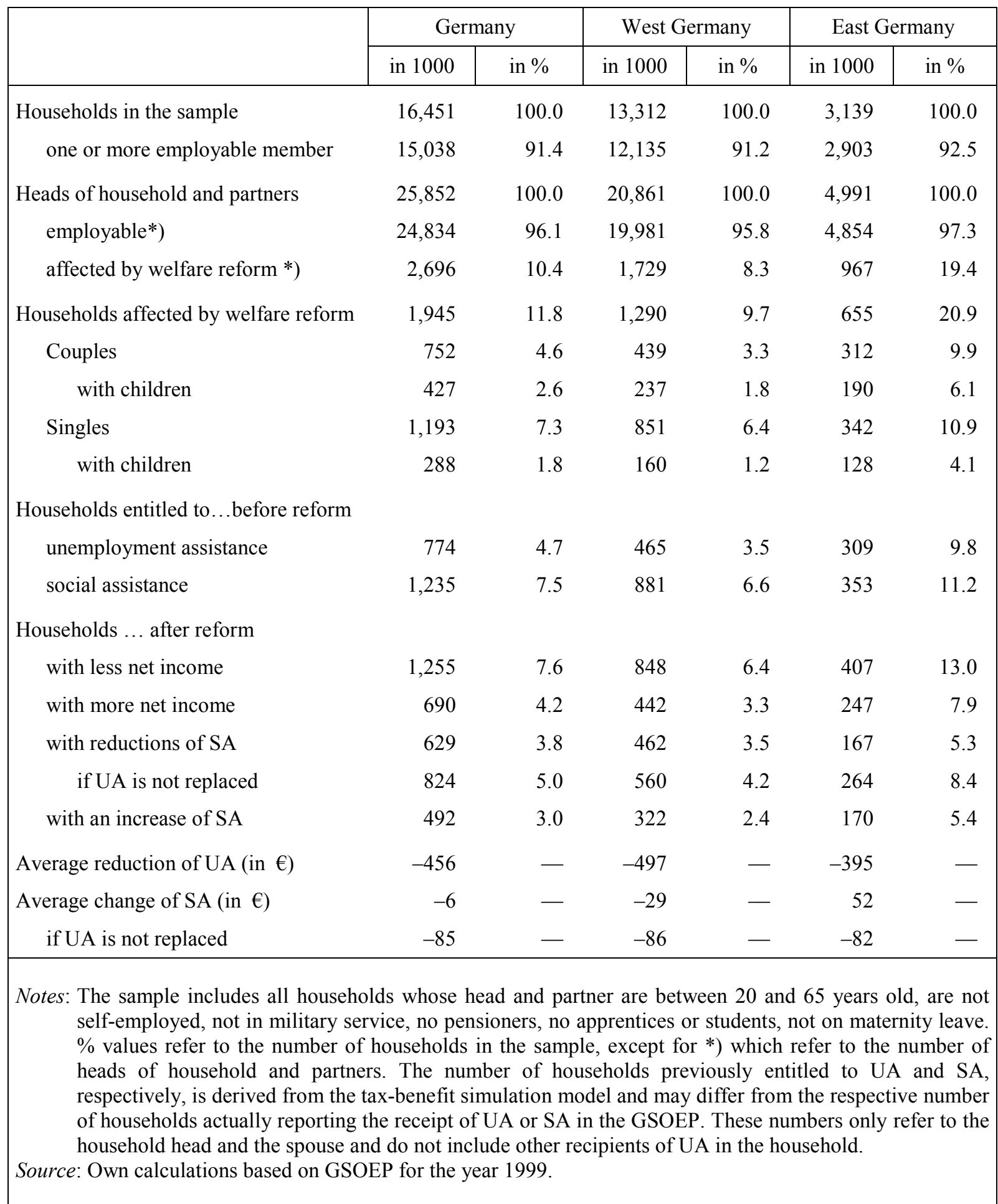

The total number of households potentially affected by the analysed welfare reform would amount to almost 2 million, or about $12 \%$ of all households in our sample. About $1 / 3$ of all households affected by the reform live in East Germany. Relative to the respective population, this amounts to almost $20 \%$ of all East German households, compared to less than $10 \%$ in West Germany. This reflects the fact that the East German population now depends to a much larger extent than West Germans on UA due to the high overall level of long-term 
unemployment in the East. Counting both heads of households and their partner about 2.7 million or roughly $10 \%$ of the respective population would be affected by the welfare reform. For East Germany this percentage is $19.4 \%$, compared to $8.3 \%$ for West Germany. The distribution by type of household shows that the reform would disproportionately affect singles in West Germany, whereas the distribution would be rather uniform across the various household types in East Germany.

About $8 \%$ of all households included in our sample would have less income due to the reform, but for about $4 \%$ of all households income would increase. The ratio between losers and winners is roughly the same in East and West Germany, although the respective percentages in East Germany are almost twice as high as in West Germany. The share of households with reductions in SA is only slightly higher than the share of households for whom either entitlement to or the level of SA would increase under the social reform. In East Germany, the increase in the share of households with an increase in SA would even slightly outweigh the share of households with reductions in SA. This can be explained by the relatively high East German share of households with entitlement to UA under current regulations. For a large share of these households the loss of UA under the social reform would be compensated for by SA. This also has the implication that, despite the substantial reduction of the SA level, the average reduction of UA in the amount of about $450 €$ per month translates into a very modest reduction of SA. In West Germany the average monthly amount spent on SA is reduced by about $30 €$, in East Germany this amount even increases by about $50 €$.

\subsection{Labour Supply and Employment Effects}

In Table 2 we summarize our simulation results for the labour supply and employment effects induced by the analysed social welfare reform. The first column shows the increase in labour force participation which, under the assumption of a given market wage, is also the employment effect induced by the reform. The second column contains the simulated employment effects for the theoretical benchmark case of a labour demand elasticity of -1 , whereas the third column contains the simulated employment effects derived on the basis of the empirical labour demand elasticities as described in section 3.3. The respective employment effects were derived by iterating wage and employment responses until an equilibrium between labour demand and supply was attained. Simulation results are reported for various household types differentiated by region. These numbers were derived by 
summing up the changes in individual participation probabilities applying weighting factors (see Appendix 4).

Table 2-Effects of the proposed social welfare reform on labour force participation ( $\Delta$ supply) and employment ( $\Delta$ employed persons) - in 1000 persons.

\begin{tabular}{|c|c|c|c|}
\hline \multirow[t]{2}{*}{ Region and household type } & \multirow{2}{*}{$\begin{array}{c}\Delta \text { supply }= \\
\Delta \text { employment } \\
\text { (no wage adjustment) }\end{array}$} & \multicolumn{2}{|c|}{$\begin{array}{c}\Delta \text { employment } \\
\text { (with wage adjustment) }\end{array}$} \\
\hline & & $\eta=-1$ & empirical $\eta$ \\
\hline West Germany & 322 & 289 & 266 \\
\hline Couples & 164 & 147 & 137 \\
\hline Men & 108 & 99 & 95 \\
\hline Women & 56 & 49 & 42 \\
\hline Singles & 158 & 141 & 129 \\
\hline Men & 53 & 48 & 46 \\
\hline Women & 106 & 94 & 84 \\
\hline East Germany & 69 & 62 & 57 \\
\hline Couples & 36 & 32 & 30 \\
\hline Men & 17 & 15 & 14 \\
\hline Women & 20 & 17 & 15 \\
\hline Singles & 33 & 30 & 27 \\
\hline Men & 6 & 5 & 5 \\
\hline Women & 28 & 25 & 23 \\
\hline Germany & 391 & 351 & 323 \\
\hline
\end{tabular}

As the simulation results in the first column of Table 2 show, the analysed welfare reform would induce an overall increase in labour supply of about 390 thousand persons. Under the assumption of a perfectly elastic labour demand curve the market wage would remain constant, and this would also be the employment effect induced by the analysed welfare reform. This increase would be mainly concentrated on West Germany. Given the much higher unemployment rate in East Germany, the relatively small labour supply effect there may seem surprising. The relatively small female labour supply elasticity estimated for East Germany (see Table A2 in Appendix 3) may be explained by the already very high labour force participation rates which are quite similar to those of East German men. In West Germany the labour supply response is distributed fairly evenly between couples and singles, 
whereas labour supply effects differ by gender within these two groups. For East Germany, differences between the various groups are too small for any meaningful interpretation.

Turning to the employment effects, simulation results differ somewhat between the benchmark case of a wage elasticity of labour demand of -1 and the simulations based on empirical elasticity estimates. For the latter case, the overall increase in employment induced by the welfare reform is about 320 thousand people. This is only slightly smaller than the simulated employment increase of 350 thousand persons derived under the benchmark elasticity of -1 . The reason for the slight difference between the two simulations is that, although the wage reduction to balance demand and supply (in terms of total hours) in the labour market is smaller for the benchmark case than for the simulations based on empirical labour demand elasticities, this is of little consequence for the size of the employment effect since employment adjustment occurs along a relatively steep labour supply curve.

Given that the assumed labour demand elasticity in the benchmark case is the same for all population groups in Table 2, the employment effects for these groups given in the second column is proportional to the respective labour supply effects discussed above. Allowing empirical labour demand elasticities to differ by gender, the simulation results in the last column of Table 2 differ little from those shown for the benchmark case. The reason is that, although wage elasticities for total hours, which are relevant for the calculation of the required wage adjustments, differ somewhat by gender ( $c f$. Table A2 in Appendix 3), these differences have little effect on employment adjustment due to the relatively small labour supply elasticities, as already discussed above.

The employment effects reported in Table 2 refer to regular private sector jobs. According to the welfare proposal analysed here employable people not working in a private sector job can avoid a reduction of SA if they take up a public-works job. As described in section 3.4, we try to estimate the number of people who may take up a public-works job rather than just except a cut in SA and continue to consume full leisure on the basis of our structural labour supply model. Thus, we compare the household's utility evaluated at the working hours the household has to work in order to receive the current social minimum with the same household's utility evaluated at zero working hours and the respective level of the social minimum as stipulated by the reform. The calculations based on the empirical estimates of our household labour supply model imply that in about $1 / 3$ of all households whose SA level would be reduced under the welfare reform either the household head or the spouse would take up a public-works job to avoid the SA cut. Hence, about 2/3 of all households would choose not to take up a full-time public-works job and accept the reduction of the SA 
level. This has implications for the estimated size of the budgetary costs of the welfare reform to which we turn now.

\subsection{Budgetary Effects}

Table 3 lists the main social expenditures affected by the analysed welfare reform, as discussed in section 3.4. In addition to expenditures for UA and SA directly paid to the recipients, these include expenditures on social security contributions for UA, health expenditures and housing subsidies. We also account for subsidies of social security contributions for currently unemployed people who become eligible under the welfare reform. The respective levels of these expenditures for the year 2001 are given in the first column of the table. The second column contains the simulated changes of the various components affected by the welfare reform. Regarding social security contributions (SSC) we assume a reduction of of $50 \%$ for people previously entitled to UA and receiving SA under the welfare reform. The rationale for this assumption is that, although there will be no tax-financed social security contributions for these people they will still be entitled to general medical treatment covered by the public health insurance system, as it is the case for recipients of SA under current regulations. The effects of the reform on the various social expenditure items are simply obtained by multiplying the numbers in the first column of the table with the respective percentage changes. The resulting changes and levels are tabulated in columns 3 and 4 , respectively.

Since UA is no longer paid after the reform, expenditures are reduced by almost 9 billion $€$ in the first year the reform becomes effective. Furthermore, under the assumption that only $50 \%$ of the level of social security contributions currently paid for recipients of UA will also be insured after the reform, expenditures on this item will be reduced by almost 2 billion $€$. On the other hand, expenditures on SA will increase by about 2 billion $€$ (about $20 \%$ ) despite the marked reduction of the SA rate for "employable" persons. This increase in SA is mainly due to compensating payments to eligible households previously entitled to UA. On the other hand, SA payments are reduced due to the estimated increase of employment which, according to our preferred estimate, amounts to about 320 thousand persons. The simulation also takes into account that about one third of all households with at least one "employable" member is likely to avoid cuts in the SA level by taking up a public-works job (see section 4.2). There is also an increase in health expenditures and housing subsidies in the amount of about 0.2 billion $€$ for those previously receiving UA which would have to be covered by SA after the introduction of the welfare reform. A similar amount would be 
required to subsidize social security contributions on low earnings. However, this is more than compensated by the additional SSC in the amount of about 1.3 billion $€$ paid by previously unemployed people.

Table 3-Budgetary effects of analysed welfare reform

\begin{tabular}{|c|c|c|c|c|}
\hline & \multirow{2}{*}{$\begin{array}{l}\text { Expenditures } \\
2001 \\
(\text { in Mio. } €)\end{array}$} & \multicolumn{2}{|c|}{ Simulated change } & \multirow{2}{*}{$\begin{array}{l}\text { Expenditures } \\
\text { and revenues } \\
\text { after reform } \\
\text { (in Mio. €) }\end{array}$} \\
\hline & & $\%$ & Mio. $€$ & \\
\hline $\begin{array}{l}\text { Unemployment } \\
\text { assistance (UA) }\end{array}$ & 8,938 & -100.00 & $-8,938$ & 0 \\
\hline $\begin{array}{l}\mathrm{SSC} \text { for UA } \\
\text { recipients }\end{array}$ & 3,839 & -50.00 & $-1,920$ & 1,920 \\
\hline $\begin{array}{l}\text { Social assistance } \\
\text { (SA) }\end{array}$ & 9,434 & 20.96 & $+1,977$ & 11,411 \\
\hline $\begin{array}{l}\text { Health expenditure } \\
\text { for SA recipients }\end{array}$ & 664 & 9.04 & +60 & 724 \\
\hline Housing subsidies & 3,541 & 4.51 & +160 & 3,701 \\
\hline Subsidies of SSC & - & - & +449 & 449 \\
\hline $\begin{array}{l}\text { SSC of additionally } \\
\text { employed people }\end{array}$ & - & - & $-1,344$ & $-1,344$ \\
\hline \multicolumn{2}{|l|}{ Net balance } & \multicolumn{3}{|c|}{$-9,555$} \\
\hline $\begin{aligned} \text { Notes: } & \text { A positive sig } \\
& \text { on simulation } \\
& \text { households ex }\end{aligned}$ & $\begin{array}{l}\text { icates expen } \\
\text { its in the th } \\
d \text { to accept } t\end{array}$ & $\begin{array}{l}\text {, a nega } \\
\text { lumn o } \\
\text { iction in }\end{array}$ & $\begin{array}{l}\text { venues. } \\
\text { and the } \\
x t) \text {. }\end{array}$ & $\begin{array}{l}\text { ations are based } \\
\text { ated number of }\end{array}$ \\
\hline
\end{tabular}

Overall, the net balance of the budgetary effects of the welfare reform proposal amounts to yearly net savings social expenditures of almost 10 billion $€$. This estimate does not include the effects of the welfare reform on tax receipts, however. The reduction in nominal wages required to balance the increased supply of labour with the demand for labour in the low wage sector, will reduce tax receipts more than proportionally because of the relatively high elasticity of the wage tax with respect to wage changes in the lower part of the distribution. This is only partly compensated by increased taxes on the wages of the additionally employed people. Although the estimation of the effect of the welfare reform on net tax receipts is beyond the scope of the present paper, it seems likely that the resulting loss in income taxes would be substantially below the amount of almost 10 billion $€$ in net savings on social expenditures.

However, one should not forget that there are also financial costs for providing publicworks jobs for those who are willing to take up jobs but do not find jobs in the private sector. 
According to our estimates, about 300 thousand public-works jobs would be required. Since there is no objective way to value the output of these jobs it is difficult to estimate the net costs of these jobs to the public sector and society in general.

\section{Summary and Conclusions}

The starting point of this paper was the recent discussion of social welfare reforms with the aim to increase work incentives in Germany, thereby reducing unemployment and social expenditures at the same time. We have argued that most proposals to increase financial incentives to take up work by some sort of wage subsidy programme or the other without reducing the social minimum are not an effective way to attain this aim. This unpleasant implication derives from the structure of the social welfare system and the rather compressed earnings structure. Thus, a successful reform which increases employment and, at the same time, avoids high marginal tax rates and contains fiscal costs, requires a marked reduction in the social minimum.

In this paper, we have analysed the employment and fiscal effects of a welfare reform with the following components: (i) an integration of unemployment assistance and social assistance; (ii) a substantial reduction of the social assistance level for "employable" persons who choose not to work; (iii) improved incentives to take up work by a combination of a reduction of the social assistance withdrawal rate and an earnings-related tax credit. We have estimated the employment and fiscal effects of this welfare reform proposal on the basis of an econometrically estimated partial-equilibrium labour supply/demand model embedded in a detailed tax-benefit microsimulation model. Our simulation results show that the proposed welfare reform would increase employment substantially, although much less than often assumed in popular policy discussions. We expect an employment increase in the regular labour market of about 300 thousand persons. Despite the much higher level of unemployment in East Germany the expected increase in employment there will be relatively small due to the the relatively small empirical labour supply elasticities there. We also expect that about 300 thousand persons entitled to social assistance will take up a public-works job in order to avoid cuts in the social assistance level.

In addition to a substantial employment increase, the introduction of the welfare reform proposal presented here would also lead to a yearly reduction in net social expenditures of almost 10 billion $€$. The lion's share of these savings comes from the integration of unemployment assistance into social assistance and the reduction of its level for those not willing to take up a regular or public-works job. Even taking into account the reduction in tax 
receipts induced by the decline in market wages, the net budgetary effect of the welfare reform will remain substantial. This may be even true if the financial costs for providing public-works jobs for those who are willing to take up jobs but do not find jobs in the private sector are taken into account, depending on how the public-works sector would be organized. 


\section{References}

Blundell, R. (2002), Welfare-to-Work, Keynes Lecture, Mimeo, IFS, London.

Blundell, R. and T. MaCurdy (1999), Labor Supply: A Review of Alternative Approaches, in: Ashenfelter, O. and D. Card (Eds.), Handbook of Labor Economics, Amsterdam, 15591695.

Buslei, H. and V. Steiner (1999), Beschäftigungseffekte von Lohnsubventionen im Niedriglohnbereich, Baden-Baden.

Buslei, H. and V. Steiner (2003), Anreizwirkungen von Lohnsubventionen - Welche Bedeutung haben sie für die aktuelle Reformdiskussion?, Vierteljahreshefte zur Wirtschaftsforschung 72 (1), 94-108.

Franz, W. (2003), Arbeitsmarktökonomik, Berlin.

Haisken-DeNew, J. P. and J. R. Frick (2001), Desktop Companion to the German SocioEconomic Panel Study (GSOEP), DIW Berlin.

Homburg, S. (2002), Arbeitslosigkeit und zweitbeste Steuer-Transfer-Systeme, Discussion Paper No. 262, Universität Hannover.

Homburg, S. (2003), Arbeitslosigkeit und soziale Sicherung, Vierteljahreshefte zur Wirtschaftsforschung 72 (1), 68-82.

McFadden, D. (1974), Conditional Logit Analysis of Qualitative Choice Behavior, in: Zarembka, P. (Ed.), Frontiers in Econometrics, New York.

Ochel, W. (2003), Welfare to Work in the U.S.: A Model for Germany?, FinanzArchiv 59, 91 119.

Sachverständigenrat [German Council of Economic Experts] (2002), Zwanzig Punkte für Beschäftigung und Wachstum, Jahresgutachten 2002/03, Wiesbaden.

Saez, E. (2002), Optimal Income Transfer Programs: Intensive versus Extensive Labor Supply Responses, Quarterly Journal of Economics 117 (3), 1039-1073.

Sinn, H.-W et al. (2002), Aktivierende Sozialhilfe: Ein Weg zu mehr Beschäftigung und Wachstum. ifo Schnelldienst 55 (9), 1-52.

Steiner, V. (1997), Kann die Effizienz der deutschen Arbeitslosenversicherung erhöht werden?; Beihefte zur Konjunkturpolitik, Zeitschrift für angewandte Wirtschaftsforschung - Applied Economics Quarterly 46, 137-168.

Steiner, V. (2000), Können durch einkommensbezogene Transfers an Arbeitnehmer die Arbeitsanreize gestärkt werden? Eine ökonometrische Analyse für Deutschland. Mitteilungen aus der Arbeitsmarkt- und Berufsforschung 33 (3), 385-395.

Steiner, V. (2002), Kombilohnmodelle - Ein Weg zur Erhöhung der Beschäftigung in Deutschland?, ifo Schnelldienst 55 (4), 5-8.

van Soest, A. (1995), Structural Models of Family Labor Supply: A Discrete Choice Approach, Journal of Human Resources 30 (1), 63-88.

Wissenschaftlicher Beirat beim Bundesministerium für Wirtschaft und Technologie (2002), Reform des Sozialstaats für mehr Beschäftigung im Bereich gering qualifizierter Arbeit, Bundesministerium für Wirtschaft und Technologie, Berlin.

Zimmermann, K. F. (2003), Beschäftigungspotenziale im Niedriglohnsektor, Vierteljahreshefte zur Wirtschaftsforschung 72 (1), 11-24. 


\section{Appendix 1: Social and Unemployment Assistance As We Know It}

As background reading for the discussion in section 2, the following facts about the German unemployment assistance and social assistance systems may be helpful for the newcomer.

Social assistance (SA) is available to every legal resident in Germany whose income from other sources is below a "social" subsistence level, the "social minimum" for short. In practice, this level is calculated on the basis of the actual expenditures of low-income households. The social minimum provides a level of income support that exceeds the physically determined subsistence level. It consists of a basic subsistence level, which we will refer to as "basic SA rate", for short, and housing costs (including heating), and may also include irregular payments and certain benefits in kind. For a single person, the basic SA rate currently is about $300 €$ per month. The overall amount of the social minimum a household may receive depends on its size and composition. It is the sum of the basic SA rates for the various household members, extra-need allowances, housing costs, and expenditures for special purposes. Extra-need allowances may be claimed by single parents and by gainfully employed recipients of SA. In the former case the amount of the allowance depends on the number and the age of the children, in the latter case the maximum amount equals the basic $\mathrm{SA}$ rate. SA is means tested with income and wealth of the person applying for social assistance as well as of the spouse and first-grade relatives taken into account, where cohabiting couples are treated as if they were married. There is a basic allowance of $25 \%$ of the basic SA rate which is not withdrawn in case of earnings from work. For earnings exceeding this amount, SA is withdrawn at a rate of $85 \%$ until half the amount of the basic SA rate is reached. For earnings exceeding this amount, the benefit withdrawal rate is $100 \%$. With the exception of specific groups, in particular the disabled and lone mothers, work is thus mandatory for recipients of SA and the welfare administration has to request as well as to support the recipient to take up available job offers. In principle, the basic SA rate has to be cut by $25 \%$ in case of rejection of a job offer. However, since the administration has no or only few public-works jobs to offer, proof of job refusal is very difficult and enforcement of this regulation weak because the social assistance administration dislikes to make the case in court.

Unemployment assistance (UA) is also means tested and paid subsequently to the exhaustion of unemployment benefits. UA is initially granted for a maximum period of 12 months, but is available as long as the recipient is registered as unemployed and passes the means test which is somewhat less stringent than for social assistance. The income-replacement ratio is $57 \%$ (with respect to net earnings in the previous job) for persons with at least one child and 53\% for persons without children. In the year 2001, the average stock of persons receiving UA was about 800 thousand persons. Since the availability is a pre-condition for being entitled to UA, all persons receiving it are "employable" in principle. However, there is only a very small share of recipients of UA with small jobs. For recipients of UA who work up to 15 hours per week, there is a basic allowance of either $20 \%$ of the UA rate or about $150 €$ per month, whichever is larger. Earnings exceeding this basic allowance are deducted at a rate of $100 \%$ from the UA benefit. In case the amount of UA falls below the social minimum, social assistance may be applied for. For those who pass the means test, UA effectively provides open-ended income support at a marginally lower rate than unemployment benefits. 


\section{Appendix 2: The Tax-Benefit Model and the Simulation of Net Household Incomes for Alternative Choices of Working Hours}

The tax-benefit simulation model, which includes all relevant components of the German tax and transfer system, is based on the GSOEP and uses data for the period 1997 to 2000. The simulations refer to the year 1999. Retrospective data on incomes and an individual's labour force state contained in the calendar data for the year 2000 are required to calculate some components of household income for the year 1999. Data for the years 1997 and 1998 are required to determine eligibility of unemployment benefits and derived unemployment assistance payments. A detailed description of the tax-benefit simulation model may be obtained by the authors upon request, here we briefly describe its main components.

As regards the calculation of taxable income, earnings from dependent employment, income from capital (interest), property rents, and other income are added to get gross household income. For the great majority of households the most important income component is earnings from dependent employment. For employed people, information on gross monthly earnings in the month before the interview is collected in the GSOEP. This information together with the hours information described above is used to calculate gross hourly wages. Hypothetical monthly earnings for each of the hours categories defined in the previous section are calculated by multiplying gross hourly earnings by the respective average number of working hours in each category. For couples, gross monthly earnings of the household are the sum of the two spouses (hypothetical) earnings in each hours category. For employed persons, it is assumed that the individual gross hourly wage in their actual hours category would be the same in each hours category. For persons not employed in the month preceding the interview, gross hourly wages are estimated on the basis of empirical wage equations. Due to item non-response wages are also missing for a non-negligible share of employed persons, for whom hourly wages are also imputed on the basis of these wage equations. Estimation results for these wage equations are available from the authors on request.

Given (estimated) hourly wages, potential monthly earnings associated with each hours category are calculated for each individual in the sample by multiplying the hourly wage with the average number of hours worked per month in each category. Potential gross earnings of each household in each of the 13 hours categories are obtained by simply adding both spouses potential earnings for all categories with positive hours. Employees social security contributions and the income tax are deducted from gross household income and social transfers are added to it to get net household income. Social transfers include child allowances, child-rearing benefits, educational allowances for students and apprentices, unemployment compensation, the housing allowance, and social assistance. Taxable income is calculated by deducting certain expenses from gross household income. The income tax is calculated by applying the income tax formula prevailing in 1999 to taxable income.

Income from self-employment is not taken into account here, because the self-employed and their relatives are not included in the analysis. Information on income from capital and rents is directly taken from the respective questions in the GSOEP. It is well known that answers to the question on capital income in particular is very unreliable because of the perceived sensitivity of this question, and there is not much one can do about this on the basis of the GSOEP. This problem does not seem too severe in the present context because it would affect estimation results only to the extent that capital income varies with the choice of a particular hours category. However, it may affect the calculation of the hypothetical level of means tested income support and thereby indirectly also the choice between employment and non-employment in some cases. 


\section{Appendix 3: Hours Categories, Labour Supply and Demand Elasticities}

Table A1—Distribution of households across hours categories

A) Couples

\begin{tabular}{|c|c|c|c|c|c|c|c|}
\hline & \multirow[b]{2}{*}{ Hours } & \multicolumn{6}{|c|}{ Men } \\
\hline & & \multicolumn{2}{|c|}{0} & \multicolumn{2}{|c|}{$1-40$} & \multicolumn{2}{|c|}{$>40$} \\
\hline \multirow{5}{*}{$\begin{array}{l}\text { Dే } \\
\text { Ẽ } \\
\dot{3}\end{array}$} & 0 & 86 & $(4.9)$ & 317 & (18.2) & 208 & $(12.0)$ \\
\hline & $1-15$ & \multirow[t]{2}{*}{32} & \multirow[t]{2}{*}{ (1.8) } & 113 & $(6.5)$ & 92 & (5.3) \\
\hline & $16-34$ & & & 184 & (10.6) & 126 & (7.2) \\
\hline & $35-40$ & \multirow[t]{2}{*}{63} & \multirow[t]{2}{*}{ (3.6) } & 243 & $(14.0)$ & 167 & (9.6) \\
\hline & $>40$ & & & 54 & $(3.1)$ & 52 & $(3.0)$ \\
\hline
\end{tabular}

B) Singles

\begin{tabular}{|c|c|c|c|c|c|c|c|c|c|}
\hline Hours & & 0 & & $1-24$ & $25-34$ & & -40 & \multicolumn{2}{|c|}{$>40$} \\
\hline Men & 53 & $(17.5)$ & \multicolumn{5}{|c|}{$155(51.2)$} & 95 & (31.3) \\
\hline Women & 98 & $(21.6)$ & 50 & (11.0) & $45 \quad(9.9)$ & 190 & $(42.8)$ & 71 & $(15.6)$ \\
\hline
\end{tabular}

Notes: The first number refers to the absolute frequency in the sample, the second number (in parentheses) to the corresponding relative frequency in percent. The hours variable used here includes paid overtime, i.e. the number of actual hours worked in the reference month. This is the number of normal hours plus paid overtime hours.

Source: Own calculations, GSOEP, wave 16 (1999).

Table A2 - Estimated own-wage elasticities of participation and hours (household labour supply model with translog utility function).

\begin{tabular}{|c|c|c|c|c|c|}
\hline & \multicolumn{2}{|c|}{ East Germany } & \multicolumn{2}{|c|}{ West Germany } \\
\hline & & Men & Women & Men & Women \\
\hline \multicolumn{6}{|l|}{ Labour supply } \\
\hline \multicolumn{6}{|c|}{ Participation (percentage points) } \\
\hline \multirow[t]{2}{*}{ Couples } & Natives & 0.08 & 0.08 & 0.12 & 0.16 \\
\hline & Foreigners & & & 0.07 & 0.05 \\
\hline \multirow[t]{2}{*}{ Singles } & Natives & 0.11 & 0.13 & 0.08 & 0.15 \\
\hline & Foreigners & & & 0.10 & 0.10 \\
\hline \multicolumn{6}{|c|}{ Total hours (percent) } \\
\hline \multirow[t]{2}{*}{ Couples } & Natives & 0.12 & 0.18 & 0.18 & 0.40 \\
\hline & Foreigners & & & 0.11 & 0.12 \\
\hline \multirow[t]{2}{*}{ Singles } & Natives & 0.20 & 0.26 & 0.15 & 0.30 \\
\hline & Foreigners & & & 0.19 & 0.19 \\
\hline \multicolumn{6}{|l|}{ Labour demand } \\
\hline \multicolumn{2}{|c|}{ Participation (percent) } & -0.65 & -0.17 & -0.65 & -0.17 \\
\hline \multicolumn{2}{|c|}{ Total hours (percent) } & -0.67 & -0.45 & -0.67 & -0.45 \\
\hline
\end{tabular}

Notes: The derivation of labour demand elasticities is described in Buslei and Steiner (1999).

Source: Buslei and Steiner (1999; chapter 4). 


\section{Appendix 4: Weighting Factors and Grossing-Up of Simulation Results}

After selection of the sample as described in section 4, about 6035 observations remain for estimation of our labour supply model. The grossing-up of this sample using the cross-section weighting factors in the GSOEP yields a population of about 25.9 million persons. Due to item non-response, only 4,233 of all 6,035 observations in our sample can be used for the simulation. This relatively large reduction is related to the severe information requirements of the tax-benefit model. The calculations of household incomes as described in Appendix 2 is based on a large number of variables and requires valid data in each of the four waves 1997 2000. To correct for potential selectivity of sample attrition due to item non-response we adjust our simulation sample in the following way:

We first divide our sample into cells, $z=1 \ldots Z$, defined by sex, nationality, marital status and number of children. Define $z^{*}$ as the set of all observations in cell $z$ with complete information on all relevant variables. To reduce sampling variance we have aggregated cells with less than 10 observations. The corrected weighting factors for person i, $h r f_{i}^{\text {new }}, \mathrm{i}=1,2, \ldots \mathrm{N}$, are derived by multiplying the original weighting factor $h r f_{i}^{\text {old }}$ by the inverse of valid observations in the respective cell, i.e.:

$$
h r f_{i}^{\text {new }}=\frac{\sum_{i \in z} h r f_{i}^{\text {old }}}{\sum_{i \in z^{*}} h r f_{i}^{\text {old }}} \times h r f_{i}^{\text {old }}
$$

The observations in the estimation sample are then weighted by these individual factors to gross-up the simulation results. The resulting population estimates are reported in Tables 3 and 4 in the main text. 